\section{Anekdoteskatten ved Universitetet i Oslo}

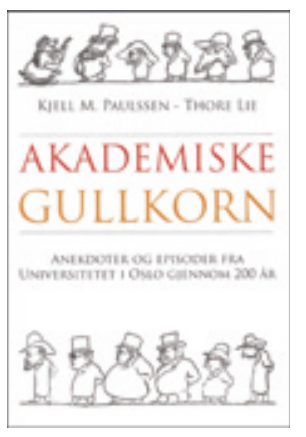

Kjell M. Paulssen, Thore Lie

\section{Akademiske gullkorn}

Anekdoter og episoder fra Universitetet i Oslo gjennom 200 år. 292 s, ill. Drøbak: Forlaget Norske Bøker, 2011. Pris NOK 249

ISBN 978-82-8112-187-4

I tidligere tider ble en professor sett på med stor aktelse og beundring. Hva de gjorde og sa ble derfor bemerket av både studenter og medarbeidere. Mange av disse var ikke bare banebrytende i faget, men også høyst originale personligheter som satte preg på omgivelsene. Ikke minst har mange av de fremstående professorene og øvrige universitetsforskerne vært anekdoteskapende.

I anledning av at Universitetet i Oslo, det tidligere Kongelige Frederiks Universitet i Christiania, fyller 200 år i 2011 har Kjell M. Paulssen og Thore Lie gitt ut en bok med anekdoter og muntre episoder fra universitetet gjennom denne perioden. Begge har et rikt kulturhistorisk forfatterskap bak seg, og sammen har de også tidligere utgitt en bok med anekdoter fra Oslos akademiske miljø generelt (1).

\section{Personen viktigere enn poenget}

En anekdote er en kort historie som sier noe karakteristisk om en navngitt person, gjerne med et morsomt poeng. Men det karakteristiske er viktigere enn at historien skal være så morsom. I så måte er det stor forskjell til en vits som er en kort, anonym historie med et overraskende poeng med det formål å påkalle latter. Mens vitsene gjerne er vandrehistorier med variasjoner over noen få temaer, viser anekdotene et stort mangfold der personen er viktigere enn selve poenget. Jo mer berømt den karikerte personen er, desto større interesse vekker historien.

Innledningsvis forklarer de hvordan enkelte personer er store anekdoteskapere som det vrimler historier om. Motsatt finnes det andre betydelige personer som det ikke verserer noen historier om. Derfor vil en anekdotesamling nødvendigvis være selektiv og sentreres om noen få, originale personligheter. Samlingen er ordnet kronologisk, og forfatterne forteller bl.a. om universitetets første år, der noen få professorer sto for det aller meste av undervisningen. Ettersom mange av våre eldre universitetslærere er gått i glemmeboken, gir forfatterne fortjenestefullt en kort biografisk presentasjon av hver omtalt person som innledning til selve anekdoten. Dette øker verdien av boken betydelig, for mange av historiene gjenspeiler forhold og miljøer som ligger langt tilbake i tid.

Flere av de eldre anekdotene i boken hører med til norgeshistorien, f.eks. de fargerike historiene som forfatterne presenterer om Henrik Wergeland (1808-45) og Johan Sebastian Welhaven (1807-73) og deres store feider. I tillegg er det flere gode historier om språkgranskeren Ivar Aasen (1813-96), og ikke minst naturforskeren Fridtjof Nansen (1861-1930). Vi blir også presentert for studentmiljøet på 1800-tallet, ulike skikker som ble innført og foreninger som oppsto. Da studentluen i sin tid ble vedtatt innført, var dette et alvorlig og meget kontroversielt tiltak! Gjennom erindringsbøkene til Halvdan Koht (1873-1965) og Carl Joachim Hambro (1885-1964) vet vi mye om studentmiljøet og universitetslærerne omkring 1900, og forfatterne har flittig referert til dem.

\section{Medisinske anekdoter}

Bare et par år etter at Universitetet i Oslo var grunnlagt, kom medisinutdanningen i gang, og en av de første medisinske professorene, Michael Skjelderup (1769-1852) blir omtalt. Ellers er det få historier om medisinere fra 1800-tallet. Derimot presenteres mange av de medisinske koryfeer fra omkring 1900 og frem mot 1960-årene. Innen de medisinske miljøene har det alltid vært en rik fortellertradisjon. Det fikk jeg selv erfare da jeg samlet inn primærstoff til en anekdotebok gjennom å intervjue eldre leger og forskere i 1970og 1980-årene (2). Svært mange av de medisinske anekdotene som Paulssen \& Lie presenterer er hentet herfra, og det føler jeg meg selvsagt beæret over. Likevel var det med en viss overraskelse jeg kan konstatere at boken inneholdt 13 sider tekst som de har satt inn i mer og mindre bearbeidet form i forhold til originalteksten min.

\section{Kilder}

Paulssen \& Lie anfører i forordet at de kun har brukt skriftlige kilder. Det er kanskje årsaken til at de har så få historier fra de siste 50 årene. En annen grunn er sikkert at personer må oppnå en viss alder og verdighet før det blir fortalt historier om dem. At mange av historiene ligger langt tilbake $\mathrm{i}$ tid, er vel også hovedgrunnen til at så få kvinner er omtalt. Hadde de foretatt innsamling av historier som verserer i dag, ville nok dette ha blitt annerledes. Bakerst i boken er det fyldig referanseliste, og dessuten har de fortjenestefullt tatt med både personregister og saksregister. Det øker anvendeligheten betydelig, for nå kan man raskt finne frem til en god historie om en aktuell person eller et aktuelt emne. Imidlertid er det problematisk at forfatterne bringer opptil et par sider tekst om gangen som er så å si direkte avskrift av annen litteratur, uten at det refereres direkte til i teksten. Selv om kildene står i referanselisten, hadde det styrket fremstillingen og verdien av boken hvis de i større grad hadde anført i selve teksten hvor den enkelte historien er hentet fra. Dette gjelder også henvisninger til primærmaterialet i min egen bok.

Alt $i$ alt har forfatterne gjort et godt arbeid med en historisk fremstilling av anekdoter fra det myldrende og fargerike universitetsmiljøet i Oslo. Boken er et funn for dem som skal holde tale og ønsker å krydre talen med helt originale historier og sitater og ikke bare standardvitser som de fleste har hørt før. Den supplerer godt tidligere anekdotesamlinger, som vi ikke har for mange av (3). Medisinerne er rikelig representert, og boken kan trygt anbefales til leger med tilknytning til universitetet både for egen bruk og som gave. Prisen er ikke avskrekkende.

\section{Ole Didrik Lærum \\ Finsenlaboratoriet Rigshospitalet \\ Københavns Universitet}

\section{Litteratur}

1. Lie T, Paulssen KM. Blant lærde og ulærde. Oslo: Grøndahl Dreyer, 1999

2. Lærum OD. Fra blodigler til datamaskin: muntre legehistorier: utgitt i forbindelse med Den norske lægeforenings 100-års-jubileum. Oslo: HjemmetFagpresseforlaget 1986

3. Dørsjø J. Levende anekdoter. Oslo: Aschehoug, 1959 